\title{
Selebrity Of Student Role In Campus
}

\author{
Ni'matuz Zuhroh \\ Postgraduate, Department of Sociology, \\ Faculty of Social and Political Sciences, \\ Brawijaya University, Malang, Indonesia \\ Darsono Wisadirana \\ Department of Sociology, \\ Faculty of Social and Political Sciences, \\ Brawijaya University, Malang, Indonesia \\ Sanggar Kanto \\ Department of Sociology, \\ Faculty of Social and Political Sciences, \\ Brawijaya University, Malang, Indonesia \\ Mardiyono \\ Department of Sociology, \\ Faculty of Social and Political Sciences, \\ Brawijaya University, Malang, Indonesia

\section{Chairul Basrun Umanailo} \\ Department of Agricultural and Forestry, \\ University of Iqra Buru, Maluku 97571, Indonesia.
}

\begin{abstract}
Celebrity students, namely students whose duties besides studying at tertiary institutions also work as celebrities, among others as models, singers, endorsements, celebrities, etc. This study aims to find out how the role of celebrity students in Malang Brawijaya University, the causes and impacts. This study uses a qualitative phenomenological approach that is described descriptively with data sources consisting of University of Brawijaya University Malang celebrities. Data collection techniques in this study are observation, interviews, and documentation. The subject selection technique used was purposive sampling and snowball technique. The research subjects were 10 celebrity students from various faculties at Brawijaya University Malang. The validity of the data in this study uses source triangulation techniques, and data analysis uses Milles and Hubberman's interactive analysis. The results of this study indicate that the students of Celebrity Brawijaya University Malang. Students are not only expected to be able to contribute their knowledge to the community in the surrounding environment but also in the campus environment as an example of the students described above. From various student labels, in this study, students contribute to campus activities at. Celebrity students in this study play a role with Miss Universe Universitas Brawijaya, MC at campus events such as Graduation events, Dies Natalis etc., there are also those who come to the invitation on behalf of students outside the institution, there are also those who love, dance at every performance held on campus .
\end{abstract}

Keywords: Celebrity Student, the role of celebrity students. 


\section{INTRODUCTION}

The Role of Celebrity Students on Campus, Students are people who study in college, whether in universities, institutes or academies. Those who are registered as students in tertiary institutions can be called students. But basically the meaning of students is not that narrow. Registered as a student in a Higher Education is only an administrative requirement to be a student, but being a student contains a broader understanding than just the administrative problem itself.

Carrying a student degree is both a pride and a challenge. Imagine, the expectations and responsibilities carried by students are so great. Students' understanding cannot be interpreted word for word. Students are agents of change(Efikasi Diri: Tinjauan Teori Albert Bandura 2016). Become someone who can provide solutions to problems faced by a nation society in various parts of the world.

Students according to Knopfemacher (in Suwono, 1978) are human beings who are candidates for involvement with tertiary institutions, are educated and are expected to become intellectual candidates. Whereas students according to Sarwono (1978) are all those who are officially registered to attend higher education with an age limit of around 18-30 years (Febriana, Winanti, and Amelia 2013). Students are a group in society that obtains their status because of ties with universities. Students are also candidates for intellectuals or young scholars in a layer of society who are often prerequisite with various predicates.

A student is categorized at the stage of development whose age is 18 to 25 years. This stage can be classified in late adolescence until early adulthood and in terms of development, the task of development at the age of these students is the establishment of a life stand (Mahoney 2012). Based on the description above, it can be concluded that the student is a student aged 18 to 25 years who is enrolled and is educated in tertiary institutions from academic, polytechnic, high school, institute and university (Widyatmoko 2014). Whereas in this study, the subjects used were two students who were 23 years old and were still listed as active students.

At the beginning of the lecture, many students will follow the learning given by lecturers, assignments, and attendance, this is a transition phase that initially only the status of students changed to students, but when they got to know the world of lectures they began to look for new things so can change behavior, way of thinking and lifestyle. This is the initial formation of the process of how a student determines the direction of his life, when he gets good friends and pious then that student's behavior will also lead to good behavior, if he befriends people who have bad behavior then it will also affect the behavior of these students .

The world of lectures on campus is very interesting to study, especially related to the role of celebrity students on campus. As a student of various kinds of labels also carried, there are several kinds of labels attached to students themselves, for example

1. Direct of Change, students can make changes directly because there are a lot of HR

2. Agent of Change, change agent student, means HR to make changes

3. Iron Stock, the human resources of the students will never run out

4. Moral Force, students are a group of people who have good morals

5. Social Control, students are controllers of social life, for example controlling social life by the community.

As one of the agents of change, a celebrity student also has a role as a student in his lectures and is able to become an empowerment cadre after changes that play a role in the physical and non-physical development of a nation which is then supported by the student's next function, 
namely social control, which covering cultural control, community control, and individual control. Students are not only required to act as observers in matters, but are also required to be able to become perpetrators in society, because it is undeniable that students are part of the community.

\section{RESEARCH METHODS}

the location of this research was conducted at Malang Malang University. Researchers were interested in knowing the role of celebrity students on the Malang Brawujaya campus. This research uses a phenomenological qualitative research method with descriptive analysis. 4) qualitative research means a research procedure that produces descriptive data in the form of written or oral words from people and observed behavior. Data can be obtained through the process of observation and interview, then processed into words that are easy to understand. Research Data Sources, through observation, interviews, documentation, and so on. Primary Data Sources, researchers by exploring the original sources of respondents. Data obtained through interviews and direct observations in the field. The primary data source in this study is the role of celebrity students on the UB campus. and secondary data, this data in the form of books, journals, and photos of activities taken during the research. And Secondary Data Sources In this study, researchers used several data collection techniques namely, observation (observation), interviews (interviews), and documentation. In this study, researchers used participant observation because the researcher was in a state of the object being studied. Researchers are in that place, to obtain valid evidence in the submitted report. The interview technique is done by making interview guidelines that are in accordance with the problems that will be used for question and answer with respondents. The type of interview the researcher uses is the approach of using interview general instructions.

The technique used in sampling in this study is purposive sampling which is a technique that aims to capture as much information from various sources (Moleong 2017). The selection of respondents is done purposively and snowball techniques, where respondents are chosen based on characteristics that meet the conditions set by the researcher, then the researcher obtains new respondents based on information from previous respondents. Initially the researchers chose 5 respondents to study, then 5 of the respondents suggested researchers to make friends who meet the requirements as the next respondent. The validity of the data in qualitative research is effort increase the degree of data trust. In this study the validity of the data used is the triangulation method.

\section{RESEARCH DISCUSSION AND FINDINGS.}

Based on the results of the research in the field, some students who became informants of the research also acted as celebrity students, including Cindy Clarissa is a Faculty of Administrative Sciences student majoring in Business semester 4 of 2018 who works as a model, Revi Riana is a student of the Faculty of Social and Political Sciences majoring in Communication in the 8th semester of 2016, who works as a model, Chikal is a student of the Faculty of Social and Political Sciences majoring in Communication in the 4th semester of 2018 who also works as a model.

The students above are certainly students who have a dual profession besides students. This is motivated by several reasons. Some of them are Arist Ramadhan Putra, one of the Brawijaya University Communication Studies students. In the interview opportunity, Aris stated:

"It has been my desire since I first entered the world of entertainment, and that desire has become stronger after I entered this Communication Science department. When the opportunity came, I didn't miss it by proposing to be a radio announcer who then drove me to the world of entertainment that I had dreamed of. " 
Other informants showed social influence attitudes in determining their life style. Azalia Fabiola Eman, for example, who is more familiarly called Ola, is quite popular in the Instagram world after uploading some of his works in music. Aside from being a student, Ola also has activities that can be considered quite dense like an influencer or celebrity lifestyle. In his interview, Ola shared stories of his activities besides being a student;

"I teach piano lessons on certain days according to the contract, then on some weekends I take a job as a model of MUA / make up, and in some spare time I also take the time to hang out and hang out with my girlfriend or friend ..."

Ola grows and develops in an art family, where her parents work as music teachers. The environment that was formed also made its own mindset for Ola. The environment not only shaped Ola's mindset, but also helped to shape the habits and abilities he possessed. There is also the Renata Fortuna that is usually called Rena. His lifestyle is influenced by the social influence of an entertainer. In everyday life Rena also shared the following story:

"Aside from being a student, every weekend I fill activities by practicing routine dance with my team, and at other leisure times I use them to take part in dance competitions and take up jobs modeling on several occasions. Sometimes I help to take care of my sister and parents' cafe ..."

Rena is known to many people through dance cover videos that she uploaded to Instagram with her dance team. On the other hand, since school age Rena has often participated in dance competitions and won on several occasions. The social influence on Rena's lifestyle as a dancer is a derivative of Rena's own sister who is an ex-dancer or former dancer / dance. This reinforces that Rena put a lifestyle based on the social influences that exist in the closest people.

On the other hand, students have an important role in the campus area and in the surrounding community. Students are not only expected to be able to contribute their knowledge to the community in the surrounding environment but also in the campus environment as an example of the students described above. From the various student labels above, in this study, students contributed to campus activities at Brawijaya University. Celebrity students in this study play a role with many of the labels described above. As Cindy Clarissa said:

"Now I go more to the embassies. Start guarding ya. So now there is the name of the campus ambassador event held annually later. The system is like the Miss Universe event. From how many people were selected"

Cindy Clarissa also added:

"That is the series of UB dies natalis. If in the old days 2017 EM children held sons and daughters of Brawijaya for dies natalis. Then in 2018 again, EM children would not do it. Finally Brarijaya's sons and daughters stand alone. Like that. "

The same thing was done by Revy Repong who contributed to activities on campus with his profession as a model and celebrity student.

"The campus is quite supportive though. Because some events use my services to fill events on campus."

The role of celebrity students has entered into the rationality of community thinking and is applied in everyday life. As stated by Chikal and Cindy Clarissa that

"If it is from the public relations party usually. The campus ambassador seemed to focus on the community, the representative form of the kids. For example, the rector needs us to welcome 
high school students who study tours. It could also be the MC at campus events sometimes also get invitations from other groups so, for example the other campus ambassadors we are invited to continue to come. if in Yogyakarta there are 24 ambassadors. Now each ambassador has his work according to the rector. I'm just an agency. You don't have it on campus. Yes, the most ambassador was. At the most, please maintain it with the campus. In this case students are expected to be more able to be responsible for what they do, and can live independently and have higher integrity. Therefore, although celebrity students are preoccupied with activities outside the lecture schedule, students still have the obligation to complete their studies. Because the community itself has a paradigm that students are a reflection of society in the future that has more educational values and broad knowledge. So that if students and the community can tolerate each other and cooperate with each other, it will form a community life that is more guaranteed the quality of knowledge and can jointly grow and develop in harmony.

In her primary activities as a student, no matter how much she had activities that exceeded the activities of most students, college activities for Cindy remained the main and priority activities, so that other activities including celebrity activities were carried out after her main task of completing the lecture obligations was fulfilled. As told:

"Lectures are prioritized, for example morning to afternoon lectures, until the house immediately makes macronies, then send to several shops (if there is no job decor). The model is done on weekends, not accepted if the offer on weekday.

Likewise for Chikal who revealed:

"If I miss all this time, I don't usually go straight to the lecturer to ask if I have an assignment or not. So that I can do my work. Organizations are usually at night. If that's the case, I prefer college. Not all taken. Or a full stop bias to focus on the test. "

Even so, that does not mean the job of being a celebrity student cannot be a choice of job after college. This was stated by Cindy Clarissa who said:

"It could be sis, yes, because it was profitable. Besides, work is not seen from graduates, right sis. "

Moral for students can be a tool of control in carrying out an action. Moral can be a picture for students in making a decision or in doing something good or bad. As learners and part of the community, students have a vital and overall role so that they can provide a change for the nation to become better. The intelligent ideas and innovations of a student as a result of critical thinking are able to change the paradigm that develops in a group of people and make it more directed according to common interests. These ideas and innovations are behind the full name Revy Tiara Zahra, and in her Instagram account (ig: revytiara). In daily life, familiarly called by the name greeting Revy In guiding an event at one private radio station. His lectures in Communication Studies must be redeemed with a UKT of Rp. 3,900,000 each semester with the support of income from parents who work as entrepreneurs. Regarding his activities, Revy related as follows:

"I really enjoy the activities that I have done so far, Alhamdulillah, I can go to college and work simultaneously. Of course many students crave it, many colleagues, lots of activity and the contents of an adequate wallet of course. "

Regarding his routine, Revy explained;

"I study from Monday to Wednesday, which every night for six days of radio broadcasts. It's not uncommon for me to get a MC job for an off air event with a salary that can be said to be fairly decent." 
In each month, Revy earns an income that can be said to be more than enough to meet his needs as a student. In this case Revy gives such calculations;

"Every month, I get a radio broadcast honorarium according to the UMR, then I am added several times by the MC when I accumulate an average of 1-2 million every month. But for certain months it can be more than 3 million because there are so many events. That kind of money is pretty good to cover the needs of students like me "

"As a student, I must have principles and convictions so that they are not easily influenced by the consumptive social environment, if you feel that the association only makes us worse, it is better to get out of the association. Look for relationships or friends who can lead to a better direction, because bad associations ruin good habits "

"Most students still feel proud to work while in college, don't be shy and don't be proud to work as long as it is halal, because it would be better if we get extra money than just squandering money on something that is not important".

"Hopefully student friends can be wiser in using money, because the way we live our lives today will be very influential with what we will get in the future".

"Most students still cannot distinguish between 'wants' and 'needs'. There are still many students who are more concerned with their desires, because the desires are related to the desires and satisfaction they get. Students also sometimes wrong in prioritizing things".

"There is nothing wrong with refreshing, but if every weekend on Friday and Saturday always hang out and the streets seem like it has become a habit that can make students become wasteful. Also for example in terms of shopping ". So complex is the role of celebrity students as learners and empowerers who are supported in a variety of activities outside of lectures. Even so, in association with college friends, celebrity students also hang out with other friends. As revealed by Revy Repong

"I usually do it, it doesn't matter. I'm actually also not that many friends on campus more often alone. Well maybe because I'm busy rarely can play it. Miss, miss. Just join me in following me. I also don't feel exclusive if I'm on campus so it's just normal. There is no difference. After all, I only rarely go to college to gather with other friends on campus. "

\section{Cindy Clarissa added}

"For me, there's nothing sis. Just mix. I also play with my friends who don't model too. No sis. Blend like normal sis. When I am on campus I am like most students. "

In the world of lectures, students who like to organize will have friends who also like to organize, those who like to fashion specifically women will also be friends with those who have the same hobby, then students who like sports will also have friends who like their hobbies, then celebrity students also have their own community scope. As Cindy Clarissa said:

"Yes, you usually get together with friends in the community. The agency community or not the community that is incorporated into the campus ambassador. "

It can be said that modern society today lives in a consumer culture. As a culture, consumption greatly influences daily life, especially students who work as celebrities. So as to be able to structure daily activities in the community. The same is true of the role of celebrity students on campus. Meaning values and self-esteem make something consumed become increasingly 
important in personal experience and social life of the community. The critical attitude of students often produces a big and meaningful change and can make leaders who are not competent or able to lead well feel hot and anxious. With the inherent characteristics of students, namely a burning sense of enthusiasm to make a change.

\section{CONCLUSION}

Based on his knowledge, level of education, norms that apply around him, and his way of thinking. It is appropriate, students become role models in society without exception of students who are double professions such as celebrity students. Therefore, the role of students is not only to study the theoretical sciences on the lecture bench but also must be applied on campus and also in the community.

\section{References}

"Efikasi Diri: Tinjauan Teori Albert Bandura." 2016. Buletin Psikologi.

Febriana, Betie, Luky Winanti, and Sandra Amelia. 2013. "Hubungan Antara Keaktifan Organisasi Dengan Prestasi Belajar (Indeks Prestasi) Mahasiswa Fakultas Ilmu Keperawatan Universitas Indonesia." Prosiding Konferensi Nasional PPNI Jawa Tengah.

Mahoney, Joseph T. 2012. “Towards a Stakeholder Theory of Strategic Management." In Towards a New Theory of the Firm: Humanizing the Firm and the Management Profession,.

Moleong, Lexy J. 2017. “Metodologi Penelitian Kualitatif (Edisi Revisi).” In PT. Remaja Rosda Karya,.

Widyatmoko, Yunindra. 2014. "Pengaruh Keaktifan Mahasiswa Dalam Organisasi Dan Prestasi Belajar Terhadap Kesiapan Kerja Mahasiswa Jurusan Pendidikan Ekonomi Universitas Negeri Yogyakarta.” Skripsi. 